\title{
SUPLEMENTASI MINERAL ESENSIAL DALAM RANSUM TERHADAP LAMA KEBUNTINGAN, MORTALITAS SELAMA MENYUSUI DAN BOBOT SAPIH PADA KELINCI (Oryctolagus cuniculus)
}

\section{(Suplementation of Essential Minerals on Feeds to Long Gestation, Mortality During Weaning and Weight Gain Post Weaning of Rabbit (Orygtolagus cuniculus))}

\author{
Kennie Cendekia Desnamrina ${ }^{1}$, Ristika Handarini ${ }^{2}$ dan Zulfikar Siregar ${ }^{3}$ \\ 1. Mahasiswa Program Studi Peternakan Fakultas Pertanian Universitas Sumatera Utara \\ 2. Staf Pengajar Program Studi Peternakan Fakultas Pertanian Universitas Djuanda \\ 3. Staf Pengajar Program Studi Peternakan Fakultas Pertanian Universitas Sumatera Utara
}

\begin{abstract}
Application of essential minerals can be effect the increased of metabolic systems and that will be increased the productivity of rabbits. The research was conducted at livestock farmers group Rehna Latersia, in the sub-district Berastagi during June to September 2012. The rabbits used in this research are 36 rabbits (27 doe and 9 bucks) with randomized block design with three block based on rabbit body weight. The three treatments are T0 (control, natural conditions), T1 (acid feed, contains of essential minerals P $0.5 \%$ and $\mathrm{Cl} 0.5 \%$ on feed) and $\mathrm{T} 2$ (base fee, contains of essential minerals $\mathrm{Na} 0.5 \%$ and $\mathrm{Ca} 0.75 \%$ on feed). The three parameters are long gestation, mortality during weaning and weight gain post weaning. The results showed not significant different all of parameters ie: long gestation, mortality during weaning and weight gain post weaning. The average length of pregnancy was highest in treatment acid feed about 31.55 days. The average of the highest mortality in treatment base feed about $21,03 \%$. The highest average post weaning in treatment base feed about $550.68 \mathrm{~g} /$ head. The conclusion showed that supplementation of essential minerals $(\mathrm{Na} 0.5 \%), \mathrm{Ca}(0.75 \%), \mathrm{P}$ $(0.5 \%)$ and $\mathrm{Cl}(0.5 \%)$ have not been able to accelerate time of partus, reducing mortality and increased weight during lactation weaning in rabbits.
\end{abstract}

Keywords : Rabbit, an essential mineral, long gestation, mortality, weaning weight

\begin{abstract}
ABSTRAK
Aplikasi mineral esensial berpengaruh terhadap peningkatan sistem metabolisme tubuh kelinci dan akan meningkatkan produktivitasnya. Tujuan penelitian untuk menguji pengaruh suplementasi mineral $\mathrm{Na}, \mathrm{Ca}$, $\mathrm{P}$ dan $\mathrm{Cl}$ terhadap kinerja reproduksi kelinci (Oryctolagus cuniculus). Penelitian telah dilakukan di Kelompok Tani Ternak Rehna Latersia, Berastagi selama bulan Juni -September 2012. Penelitian ini menggunakan 36 ekor kelinci (27 ekor betina dan 9 ekor jantan) dengan rancangan acak kelompok, terdiri atas tiga kelompok yang dibedakan berdasarkan bobot badan kelinci. Ada tiga perlakuan yaitu T0 sebagai pakan kontrol, T1 pakan bersifat asam (mengandung mineral $\mathrm{P} 0,5 \%$ dan $\mathrm{Cl} 0,5 \%$ ) dan $\mathrm{T} 2$ pakan bersifat basa (mengandung mineral $\mathrm{Na}$ $0,5 \%$ dan $\mathrm{Ca} 0,75 \%$ ). Parameter yang diamati adalah lama kebuntingan, mortalitas selama menyusui dan bobot sapih. Hasil penelitian menunjukkan bahwa suplementasi mineral pada ransum kelinci tidak berpengaruh terhadap semua parameter. Rataan lama kebuntingan tertinggi pada perlakuan asam sebesar 31,55 hari. Rataan mortalitas tertinggi pada perlakuan basa sebesar $21,03 \%$. Rataan bobot sapih tertinggi yaitu 550,68 gr/ekor pada perlakuan basa. Kesimpulan menunjukkan bahwa suplementasi mineral esensial (Na 0,5\%), Ca (0,75\%), P $(0,5 \%)$ dan $\mathrm{Cl}(0,5 \%)$ belum dapat mempercepat waktu kelahiran, mengurangi angka mortalitas selama menyusui dan meningkatkan bobot sapih pada kelinci.
\end{abstract}

Kata kunci : Kelinci, mineral esensial, lama kebuntingan, mortalitas, bobot sapih 


\section{PENDAHULUAN}

Meningkatnya populasi penduduk erat kaitannya dengan meningkatnya kebutuhan pangan. Sumber-sumber pangan yang terus meningkat meliputi semua zat nutrisi yang dibutuhkan oleh tubuh, termasuk kebutuhan protein terutama protein hewani. Melihat angka ketersediaan sumber protein hewani yang berada jauh dibelakang angka populasi penduduk membutuhkan alternatif yang cepat dan tepat, salah satunya adalah bioteknologi reproduksi.

Campur tangan manusia dibutuhkan untuk meningkatkan populasi sumber protein hewani, mulai dari memilih jenis ternak sumber protein hingga perbanyakan ternak tersebut. Kelinci bisa jadi pilihan menarik dengan keunggulan yang dapat dilestarikan. Daging kelinci disamping kandungan proteinnya tinggi, rasanya lezat dan kadar lemaknya rendah. Oleh karena itu ternak kelinci dapat diikut sertakan untuk mengatasi masalah kekurangan protein hewani di Indonesia.

Kelinci adalah mamalia yang memiliki siklus reproduksi yang singkat, mempunyai kemampuan menghasilkan anak banyak dalam satu kali kelahiran (politocus), sehingga dapat menjadi alternatif untuk memenuhi kebutuhan protein hewani. Kemampuan politocus itu juga lebih baik jika dikendalikan dengan meningkatkan daya hidup selama periode prasapih, sehingga tidak menurunkan populasi saat sapih hingga dewasa.

Kasus yang terjadi dibeberapa peternakan kelinci menunjukkan bila kematian selama menyusui sering terjadi hingga hanya sebagian dari anak kelinci yang mampu bertahan hidup hingga masa sapih, akibatnya perbanyakan dinilai lebih lama. Penggunaan mineral telah lama diaplikasikan oleh masyarakat kepada ternak. Tujuannya untuk meningkatkan produktifitas ternak dalam memproduksi daging dan susu. Aplikasi mineral akan membuat sistem metabolisme tubuh semakin baik, hingga produktifitas dapat ditingkatkan.

Berdasarkan uraian diatas, penulis tertarik untuk melakukan penelitian lebih lanjut menggunakan mineral makro esensial, dengan harapan meningkatkan daya hidup anak kelinci.

\section{BAHAN DAN METODE}

\section{Lokasi dan Waktu Penelitian}

Penelitian ini dilaksanakan di Kelompok Tani Ternak "Rehna Latersia", Berastagi pada bulan Juni hingga September 2012. Pembuatan pellet dilakukan di Compost Center Fakultas Pertanian USU. 


\section{Bahan dan Alat Penelitian}

Bahan yang digunakan adalah kelinci lokal. Kelinci betina yang sudah pernah melahirkan dengan kisaran umur 1-1,5 tahun sebanyak 27 ekor. Kelinci jantan berasal dari keturunan yang sama sebanyak 9 ekor. Ransum dengan tiga perlakuan yaitu kontrol, asam dan basa. Rodalon ${ }^{\circledR}$ sebagai desinfektan kandang.

Alat yang akan digunakan adalah kandang individu yang berukuran $80 \mathrm{~cm}$ x $80 \mathrm{~cm} \mathrm{x}$ $70 \mathrm{~cm}$ sebanyak 36 petak. Kandang dibagi menjadi 27 petak untuk kelinci betina dan 9 petak untuk kelinci jantan. Pencetak pellet untuk pembuatan ransum berupa pellet. Tempat pakan dan minum pada tiap kandang, termometer, kertas $\mathrm{pH}$, timbangan digital berkapasitas $5 \mathrm{~kg}$ dengan kepekaan 0,01 g, kamera digital, pembersih kandang (sapu, sikat lantai dan ember), alat tulis, buku data dan kalkulator.

Ransum disusun dari beberapa bahan dalam bentuk pellet, formula ransum yang digunakan untuk kelinci bunting dapat dilihat pada Tabel 1, dan kelinci laktasi pada Tabel 2.

Tabel 1. Formula ransum kelinci bunting

\begin{tabular}{lccc}
\hline \multicolumn{1}{c}{ Bahan pakan } & T0 (\%) & T1 (\%) & T2 (\%) \\
\hline Tepung jagung & 40 & 40 & 40 \\
Bungkil Inti Sawit & 15 & 15 & 15 \\
Bungkil kedelai & 15 & 15 & 15 \\
Dedak halus & 19 & 20 & 20 \\
Molasses & 10 & 9,13 & 9,05 \\
Garam & 0,5 & - & - \\
Mineral mix & 0,5 & - & - \\
$\mathrm{NH} 4 \mathrm{Cl}$ & - & 0,5 & - \\
$\left(\mathrm{NH}_{4}\right)_{3} \mathrm{PO}_{4}$ & - & 0,37 & - \\
$\mathrm{Na}_{2} \mathrm{CO}_{3}$ & - & - & 0,5 \\
$\mathrm{CaCO}_{3}$ & - & - & 0,45 \\
\hline
\end{tabular}

Tabel 2. Formula ransum kelinci laktasi

\begin{tabular}{lccc}
\hline \multicolumn{1}{c}{ Bahan pakan } & $\mathrm{T} 0(\%)$ & $\mathrm{T} 1(\%)$ & $\mathrm{T} 2(\%)$ \\
\hline Tepung jagung & 40 & 40 & 40 \\
Bungkil Inti Sawit & 15 & 15 & 15 \\
Bungkil kedelai & 20 & 20 & 20,25 \\
Dedak halus & 14 & 15 & 15 \\
Molasses & 10 & 9 & 8,5 \\
Garam & 0,5 & - & - \\
Mineral mix & 0,5 & - & - \\
$\mathrm{NH} 4 \mathrm{Cl}$ & - & 0,5 & - \\
$\left(\mathrm{NH}_{4}\right)_{3} \mathrm{PO}_{4}$ & - & 0,5 & - \\
$\mathrm{Na}_{2} \mathrm{CO}_{3}$ & - & - & 0,5 \\
$\mathrm{CaCO}_{3}$ & - & - & 0,75 \\
\hline
\end{tabular}




\section{Metode Penelitian}

Metode penelitian yang digunakan adalah dengan menggunakan rancangan acak kelompok (RAK) dengan 3 perlakuan dan 3 kelompok. Perlakuan yang digunakan yaitu :

$\mathrm{T}_{0}=$ Tanpa suplementasi mineral (kontrol)

$\mathrm{T}_{1}=$ Suplementasi mineral $\mathrm{NH}_{4} \mathrm{Cl} 0,5 \%$ dan $\left(\mathrm{NH}_{4}\right)_{3} \mathrm{PO}_{4} 0,5 \%$ dalam ransum

$\mathrm{T}_{2}=$ Suplementasi mineral $\mathrm{Na}_{2} \mathrm{CO}_{3} 0,5 \%$ dan $\mathrm{CaCO}_{3} 0,75 \%$ dalam ransum

Kelompok yang digunakan yaitu:

$\mathrm{K} 1=$ bobot badan $1,45 \mathrm{~kg} \pm 0,20$

$\mathrm{K} 2=$ bobot badan $2,51 \mathrm{~kg} \pm 0,21$

$\mathrm{K} 3=$ bobot badan $3,63 \mathrm{~kg} \pm 0,33$

Menurut Sastrosupadi (2000), metode linier percobaan yang digunakan adalah:

$$
\mathrm{Yij}=\mu+\mathrm{Ti}+\beta \mathrm{ij}+\sum \mathrm{ij}
$$

Keterangan:

$\mathrm{i}=1,2, \ldots \mathrm{t}$ (perlakuan)

$\mathrm{j}=1,2, \ldots \mathrm{r}$ (ulangan)

Yij $=$ respon/nilai pengamatan pada perlakuan ke-i kelompok ke-j

$\mu \quad=$ nilai tengah umum.

$\mathrm{Ti}=$ pengaruh perlakuan ke-i.

$\mathrm{Bij}=$ pengaruh kelompok ke-j

$\sum \mathrm{ij}=$ pengaruh galat percobaan perlakuan ke-i dan kelompok $\mathrm{j}$.

\section{Parameter Penelitian :}

1. Lama kebuntingan

Lama kebuntingan diperoleh dengan menghitung jarak antara perkawinan pertama dengan waktu kelahiran.

2. Mortalitas selama menyusui (\%)

Perbandingan antara jumlah anak yang mati dengan jumlah anak yang dilahirkan

3. Bobot sapih (gram / ekor)

Bobot sapih adalah berat anak saat sapih diperoleh dari rata-rata bobot anak saat sapih dari setiap induk. 


\section{HASIL DAN PEMBAHASAN}

Hasil penelitian suplementasi mineral dalam ransum terhadap lama kebuntingan, mortalitas selama meyusui dan bobot sapih pada kelinci tersaji dalam Tabel. 1.

Tabel 3. Rekapitulasi suplementasi mineral esensial dalam ransum selama masa penelitian

\begin{tabular}{cccc} 
Perlakuan & $\begin{array}{c}\text { Lama kebuntingan } \\
\text { (hari) }\end{array}$ & $\begin{array}{c}\text { Mortalitas } \\
(\%)\end{array}$ & $\begin{array}{c}\text { Bobot sapih } \\
\text { (g/ekor) }\end{array}$ \\
\hline T0 & $31,22^{\text {tn }} \pm 0,44$ & $13,22^{\text {tn }} \pm 18,89$ & $473,67^{\text {tn }} \pm 14,99$ \\
T1 & $31,55^{\text {tn }} \pm 0,73$ & $15,46^{\text {tn }} \pm 19,96$ & $507,91^{\text {tn }} \pm 61,36$ \\
T2 & $31,33^{\text {tn }} \pm 0,87$ & $21,03^{\text {tn }} \pm 20,65$ & $550,68^{\text {tn }} \pm 114,52$ \\
\hline
\end{tabular}

Keterangan: $\mathrm{tn}=$ tidak nyata

\section{Lama Kebuntingan}

Lama kebuntingan adalah periode dari mulai terjadinya fertilisasi sampai terjadinya kelahiran. Rekapitulasi data menunjukkan rataan lama kebuntingan tertinggi secara keseluruhan terdapat pada perlakuan T1 (suplementasi mineral asam) yaitu 31,55 hari dan terendah pada perlakuan T0 (kontrol) yaitu 31,22 hari.

Hasil yang didapatkan setelah dilakukan analisis ragam pada data lama kebuntingan menunjukkan bahwa hasil penelitian berbeda tidak nyata $(\mathrm{P}>0,05)$. Pada Tabel 3 dapat dilihat angka lama kebuntingan rata-rata sekitar 31 hari. Hal ini sesuai dengan pernyataan Sarwono (2002) yang menyatakan bahwa kelahiran untuk kelinci terjadi 31-32 hari sesudah perkawinan berlangsung. Rata-rata kebuntingan pada ternak kelinci adalah 31 hari yang dipengaruhi oleh waktu kawin. Soemarno (2012) juga menyatakan hal serupa yaitu setelah perkawinan kelinci akan mengalami kebuntingan selama 30-32 hari dan dapat dideteksi dengan meraba perut kelinci betina 12-14 hari setelah perkawinan. Kelinci akan lahir antara umur 28-34 hari, namun kebanyakan kelinci melahirkan pada usia kandungan 29-30 hari.

Lama kebuntingan sangat dipengaruhi oleh kecukupan pakan. Kondisi induk akan memburuk jika pakan kurang. Jika induk tidak mampu mempertahankan kondisi tubuh, maka anak tidak mendapatkan cukup nutrisi untuk pertumbuhan. Hal yang paling memungkinkan adalah terjadinya kematian embrio dalam uterus. Pada akhirnya gejala ini dapat memungkinkan anak untuk tinggal lebih lama di dalam tubuh induk (Karim, 2000).

\section{Mortalitas selama Menyusui}

Mortalitas selama menyusui merupakan jumlah anak kelinci yang mengalami kematian selama masa menyusui dibagi dengan total anak kelinci yang dilahirkan oleh seekor induk dikali dengan 100\%. Rataan mortalitas tertinggi terdapat pada pelakuan T2 
(suplementasi mineral basa) yaitu $21,03 \%$ sedangkan mortalitas terendah pada T0 (kontrol) yaitu $13,07 \%$.

Analisis ragam menunjukkan hasil yaitu perlakuan pemberian mineral memberikan pengaruh yang berbeda tidak nyata $(\mathrm{P}>0,05)$ terhadap mortalitas anak kelinci selama menyusui. Sekawan (2010) menyatakan bahwa mortalitas pada kelinci pra sapih sebesar 14,7-23,3\%. Angka rataan mortaitas yang didapatkan pada penelitian ini berada diantara angka tersebut yaitu sebesar 13-21\%. Sarwono (2002) menyatakan hal serupa yaitu angka kematian anak kelinci tinggi, dapat mencapai 20-25\%, sedangkan Sumaprastowo (1993) menyatakan bahwa kematian anak kelinci dapat mencapai 30-40\% selama anak disusui. Semua pernyataan tersebut sesuai dengan data yang didapatkan selama penelitian dilaksanakan.

Angka mortalitas tertinggi didapatkan pada saat anak kelinci berumur 0-7 hari. Anak kelinci mati pada waktu kelahiran karena kondisi yang lemah dan waktu kelahiran yang lebih lama serta dapat disebabkan karena ukuran anak kelinci yang terlampau kecil atau terlampau besar. Hal lain yang dapat menyebabkan angka mortalitas pada anak kelinci yaitu manajemen pemeliharaan. Setiap 2 atau 3 hari sekali dilakukan pengecekan jumlah anak kelinci dengan melihat ke dalam kotak sarang, menghitung jumlah anak dan melihat kondisi anak kelinci. Setiap hari pada saat 2 minggu pertama setelah kelahiran ketika pemberian pakan dan pembersihan kandang dilihat juga apakah terdapat anak kelinci yang keluar dari kotak sarang untuk dikembalikan ke dalam kotak sarang anak. Pengecekan pada minggu pertama setelah kelahiran sangat diperlukan untuk mengetahui apakah induk menyusui anaknya atau tidak. Angka mortalitas anak kelinci pada minggu kedua sampai sapih tidak terlampau tinggi, bahkan tidak terdapat kematian anak kelinci. Hal ini sesuai dengan pernyataan Kharisma (2007) yang menyatakan bahwa jumlah kematian terbanyak terjadi pada umur 0-1 minggu. Tingkat kematian menurun drastis setelah anak mencapai umur lebih dari satu minggu. Periode umur 2-5 minggu terjadi kecenderungan nilai mortalitas yang semakin sedikit. Menurut Yulianto (2012) jumlah kematian kelinci cukup tinggi, bisa berkisar antara 15\%$40 \%$. Kematian yang paling tinggi terjadi dari masa kelahiran hingga penyapihan.

Kematian anak kelinci pada minggu kedua sampai sapih disebabkan karena kondisi fisik anak kelinci yang lemah. Kondisi anak kelinci yang lemah tersebut dapat menyebabkan anak kelinci yang lahir dalam jumlah litter size yang besar dan induk yang memproduksi air susu dengan jumlah terbatas akan sulit berkompetisi dengan anak kelinci lainnya untuk mendapatkan asupan air susu dari induk sehingga anak kelinci tersebut bisa mati karena kekurangan asupan gizi untuk tubuhnya. Hal ini sesuai dengan pernyataan Sumoprastowo 
(1993) dalam Limbong (2008) bahwa produksi air susu yang kurang akan memberi pengaruh terhadap mortalitas anak selama menyusui.

\section{Bobot Sapih}

Bobot sapih merupakan rataan bobot anak kelinci saat sapih diperoleh dari penimbangan anak kelinci pada waktu sapih (35 hari). Rataan bobot sapih terbesar terdapat pada perlakuan T2 (suplementasi mineral basa) sebesar 550,68 gram/ekor sedangkan bobot sapih terkecil pada perlakuan T0 (kontrol) sebesar 473,67 gram/ekor. Rataan bobot sapih anak kelinci pada perlakuan T0 (kontrol) yaitu perlakuan tanpa suplementasi mineral esensial merupakan rataan terendah. Hal ini menunjukkan bahwa ada pengaruh baik dari suplementasi mineral esensial dalam ransum induk terhadap air susu yang dihasilkan dan dikonsumsi oleh anak kelinci sehingga bobot sapih anak kelinci lebih besar dibandingkan dengan anak kelinci yang dalam ransum induknya tidak diberikan suplemen mineral esensial.

Hasil analisis ragam menunjukkan bahwa perlakuan pemberian mineral memberikan pengaruh yang berbeda tidak nyata $(\mathrm{P}>0,05)$ terhadap bobot sapih anak kelinci. Bobot sapih anak kelinci yang pakannya tidak disuplementasi mineral esensial bobot sapih anak kelici hanya berkisar antara 250 - $450 \mathrm{~g}$ /ekor. Pengamatan lapangan tersebut dapat dilihat bobot sapih anak kelinci pada saat penelitian dengan induk yang mengkonsumsi pakan suplementasi mineral esensial lebih baik karena bobot sapihnya lebih besar yaitu berkisar antara 430,8 g/ekor sampai $840 \mathrm{~g} /$ ekor dengan rataannya sebesar 510,75 g/ekor.

Lama waku penyapihan dan pemberian pakan yang baik juga menentukan bobot sapih anak. Waktu penyapihan anak kelinci adalah 5 minggu yaitu sekitar 35 hari. Hal tersebut dilakukan karena induk kelinci menghasilkan air susu secara optimum hanya sampai 32-35 hari. Selain itu anak kelinci disapih pada umur 35 hari karena anak kelinci sudah bisa mengkonsumsi hijauan dan pellet pada umur 5 minggu, sehingga anak kelinci sudah bisa dipisahkan dari induknya. Hal ini sesuai dengan pernyataan Manshur (2009) yaitu masa menyusui anak kelinci selama 35 hari.

Rismunandar (1990) dalam Sembiring (2008) menyatakan semakin lama disapih makin baik, tapi jumlah anak yang lahir dalam pertahun akan berkurang. Dimana cepat lambatnya waktu sapih dan kondisi induk sangat berpengaruh terhadap bobot sapihnya. Lama waktu pemeliharaan dan pakan yang bagus akan mempengaruhi bobot sapih. Lama penyapihan juga akan mempengaruhi berat sapihnya.

Tabel 3 menunjukkan korelasi antara angka mortalitas dan angka bobot sapih. Semakin tinggi angka mortalitas maka semakin tinggi pula angka bobot sapih. Dapat dilihat 
pada perlakuan T2 (suplementasi mineral basa) angka mortalitasnya sebesar 21,03\% merupakan yang tertinggi diantara perlakuan yang lain dan angka bobot sapih yang diperoleh sebesar 550,68 g/ekor juga merupakan angka bobot sapih terbesar diantara perlakuan lainnya. Hal ini dapat disebabkan karena berkurangnya jumlah anak yang menyusui pada seekor induk maka jumlah air susu yang diproduksi oleh induk semakin lebih banyak dikonsumsi oleh setiap anak kelinci.

\section{KESIMPULAN}

Suplementasi mineral esensial ( $\mathrm{Na} 0,5 \%), \mathrm{Ca}(0,75 \%), \mathrm{P}(0,5 \%)$ dan $\mathrm{Cl}(0,5 \%)$ belum dapat mempercepat waktu kelahiran, mengurangi angka mortalitas selama menyusui dan meningkatkan bobot sapih pada kelinci.

\section{DAFTAR PUSTAKA}

Karim, L., 2000. Produktivitas Induk Kelinci Muda Persilangan Pada Bobot Hidup Lebih dari Dua Kilogram. Skripsi. Institut Pertanian Bogor, Bogor.

Kharisma, T., 2007. Performa Reproduksi Kelinci Peranakan New Zealand White dengan Ransum Yang Mengandung Ampas Teh (Camellia sinensis) dan Tambahan Zn. Skripsi. Institut Pertanian Bogor, Bogor.

Limbong, S. R., 2008. Pengaruh Frekuensi Perkawinan dan Sex Ratio Terhadap Lama Bunting dan Litter Size Pada Kelinci Persilangan. Skripsi. Universitas Sumatera Utara. Medan.

Manshur, F., 2009. Ternak Uang Bersama Kelinci: Menjadi Jutawan Sambil Menyalurkan Hobi. Nuansa. Bandung.

Rismunandar. 1990. Meningkatkan Konsumsi Protein dengan Beternak Kelinci. Sinar Baru. Bandung.

Sarwono. 2002. Kelinci Potong Dan Hias. Agromedia. Jakarta.

Sastrosupadi, A., 2000. Rancangan Percobaan Praktis Bidang Pertanian. Kanisius. Jakarta.

Sekawan, I.K. 2010. Cara Pemeliharaan Kelinci. Storexkelinci.blogspot.com diakses 1-42012 pukul 18:15.

Sembiring, D. L., 2008. Perngaruh Frekuensi Perkawinan dan Sex Ratio Terhadap Litter Size, Bobot Lahir, Mortalitas Selama Menyusui dan Bobot Sapih Pada Kelinci Persilangan. Skripsi. Universitas Sumatera Utara. Medan.

Soemarsono, D., 2012. Budidaya dan Bisnis Kelinci. Araska. Yogyakarta.

Sumaprastowo, 1993. Beternak Kelinci Idaman. Bhratara, Jakarta.

Yulianto, A., 2012. Budidaya Kelinci. Javalitera, Yogyakarta. 